\title{
Stuck with pancytopenia in dengue fever: Evoke for hemophagocytic syndrome
}

\author{
Manoj Lakhotia, Hans Raj Pahadiya, Ronak Gandhi, Gopal Raj Prajapati, Akanksha Choudhary
}

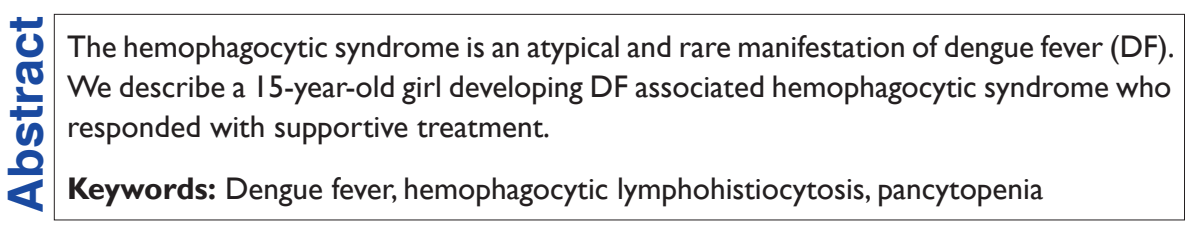

\section{Introduction}

The hemophagocytic lymphohistiocytosis (HLH) is a hyperinflammatory condition which is caused by hypercytokinemia due to excessively stimulated but ineffective immune response. The primary HLH is a familial condition, manifests in early life, and has a very poor prognosis without treatment including chemotherapy, immunotherapy, and stem cell transplantation. The secondary HLH is more often acquired following various infections, malignancy, and/or autoimmune disorders and can be successfully treated with therapy against the causative organism with steroids. ${ }^{[1-3]}$ The most common virological agent that was responsible for HLH is Epstein-Barr virus. ${ }^{[4]}$ In the present era, dengue viral infection is leading organism responsible for secondary HLH in tropical countries. ${ }^{[5,6]}$ Here, we report a 15 -year-old girl developing dengue fever (DF) associated reactive hemophagocytic syndrome who responded with supportive treatment.

\section{From:}

Department of Medicine, Dr. S.N. Medical College, Jodhpur, Rajasthan, India

\section{Correspondence:}

Dr. Hans Raj Pahadiya, Department of Medicine, Dr. S.N. Medical College, Jodhpur - 342 001, Rajasthan, India.

E-mail: drhans05sms@gmail.com

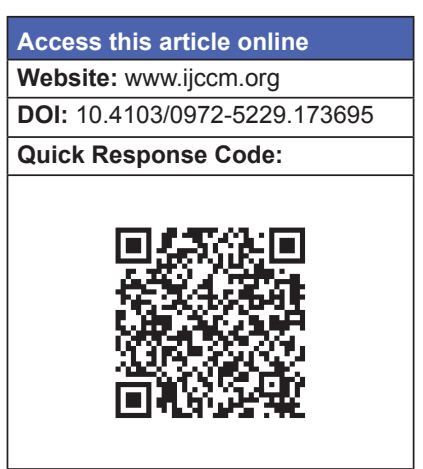

\section{Case Report}

A 15-year-old previously healthy girl came to our hospital because of history of 7 days duration of high-grade fever. She also had complaints of arthralgia, back pain, and myalgia. On examination, she was febrile, and there were no rashes, petechiae, hematuria, hematemesis, or hemoptysis. The blood pressure was $120 / 80 \mathrm{mmHg}$, pulse rate 102 beats/min, respiratory rate 18 breaths/min, and temperature was $38.4^{\circ} \mathrm{C}$ by axilla. Cardiovascular and respiratory system revealed no significant abnormality. Hematology revealed pancytopenia with a hemoglobin level of 8.8 $\mathrm{g} / \mathrm{dL}$, leukocyte count $1510 / \mathrm{mm}^{3}$ with differential count of $43.1 \%$ neutrophils, $47 \%$ lymphocytes, $4.6 \%$ monocytes, and $4.6 \%$ eosinophils, and platelets were $19,000 / \mathrm{mm}^{3}$. Serum bilirubin was $1.03 \mathrm{mg} / \mathrm{dL}$, alanine

This is an open access article distributed under the terms of the Creative Commons Attribution-NonCommercial-ShareAlike 3.0 License, which allows others to remix, tweak, and build upon the work non-commercially, as long as the author is credited and the new creations are licensed under the identical terms.

For reprints contact: reprints@ @edknow.com

\footnotetext{
How to cite this article: Lakhotia M, Pahadiya HR, Gandhi R, Prajapati GR, Choudhary A. Stuck with pancytopenia in dengue fever: Evoke for hemophagocytic syndrome. Indian J Crit Care Med 2016;20:55-6.
} 
aminotransferase $294 \mathrm{IU} / \mathrm{L}$, aspartate aminotransferase $145 \mathrm{IU} / \mathrm{L}$, and lactate dehydrogenase was $461 \mathrm{IU} / \mathrm{L}$. Renal function tests, electrolytes, chest X-ray, and electrocardiogram were within normal limit. NS1 antigen and IgM antibodies were positive for dengue virus. She tested negative for malaria, HIV, hepatitis B surface antigen, hepatitis $C$ virus, and chikungunya. Urine analysis was sterile. Ultrasonography showed mild bilateral pleural effusion, mild ascites, mild hepatomegaly, and marginal splenomegaly. The serum triglyceride level was $377 \mathrm{mg} / \mathrm{dL}$, serum ferritin >2000 ng/ml, and plasma D-dimer was high. Bone marrow aspiration showed mild hypocellular marrow with increase in macrophages and monocytes activity. Few macrophages were seen with engulfed platelets and neutrophils within it.

The diagnosis of DF with hemophagocytic syndrome was confirmed by evidence of fever with positive serological tests, hypertriglyceridemia, hyperferritinemia, splenomegaly, and bone marrow hemophagocytes. She was treated with intravenous fluids and antipyretics. We discharged her on the $10^{\text {th }}$ day in hemodynamically stable and afebrile condition with normal hematological parameters.

\section{Discussion}

The characteristic clinical and laboratory features of HLH are prolonged fever, organomegaly, hyperferritinemia, hypertriglyceridemia, hypofibrinogenemia, and hemophagocytes in the bone marrow. The diagnostic criteria of HLH by histiocytic society are revised. ${ }^{[2]}$ In HLH, there is overstimulation of macrophages or monocytes that leads to exaggerated activity of inflammatory reaction because of overproduction of various pro-inflammatory cytokines interferon- $\gamma$, tumor necrosis factor- $\alpha$ (TNF- $\alpha$ ), interleukin-6 (IL-6), IL-10, and the macrophage colony stimulating factor. These activated cells engulf the red blood cells, thrombocytes, and white blood cells leading to cytopenia. The activity of natural killer cells decreases in HLH. The pathophysiology of HLH in DF is poorly understood; dengue virus is considered as a triggering agent. The presence of prolonged fever, dengue hemorrhagic fever (DHF), and dengue shock syndrome (DSS) with multiorgan failure is predisposing conditions for HLH. ${ }^{[6]}$ In the immunopathogenesis of the disease, there is release of acute-phase response proteins and cytokines, such as TNF- $\alpha$, interferon- $\gamma$, IL-2, IL-6, IL-8, and IL-10 from the virus-infected cells. ${ }^{[7]}$

DHF and DSS are common after secondary infections of the dengue viral serotype in a previously infected individual with heterogeneous dengue virus serotype.
The cross-reactivity of the second antibody response at the T-lymphocyte level results in excessive release of various inflammatory markers that leads to DHS and DSS by causing capillary leak syndrome. ${ }^{[8]}$ These inflammatory markers may be possible pathogenetic mediators of HLH in dengue infection. ${ }^{[4]}$ Interferon- $\gamma$ is also considered as a potent activator of macrophages and may be responsible for exaggerated T-lymphocyte response. ${ }^{[9]}$ Removing of the triggering agent of $\mathrm{HLH}$, inhibition of exaggerated inflammatory reaction, supportive treatment, corticosteroids, and chemotherapy if required is the mainstay of the treatment of secondary HLH. ${ }^{[10]}$

Our case developed reactive HLH in DF; she had no evidence of DHF and DSS. She responded with supportive treatment without giving steroids and showed clinical and biochemical resolution of the hemophagocytosis. Because of rarity of HLH in DF and good response to supportive therapy, we add an additional case in the literature. We conclude that HLH is an atypical presentation of dengue infection. The clinicians should consider the possibility of viral induced secondary HLH in patients presenting with dengue infection with pancytopenia.

\section{Financial support and sponsorship Nil.}

\section{Conflicts of interest}

There are no conflicts of interest.

\section{References}

1. Rajagopala S, Singh N, Agarwal R, Gupta D, Das R. Severe hemophagocytic lymphohistiocytosis in adults-experience from an intensive care unit from North India. Indian J Crit Care Med 2012;16:198-203.

2. Henter JI, Horne A, Aricó M, Egeler RM, Filipovich AH, Imashuku S, et al. HLH-2004: Diagnostic and therapeutic guidelines for hemophagocytic lymphohistiocytosis. Pediatr Blood Cancer 2007;48:124-31.

3. Janka G, zur Stadt U. Familial and acquired hemophagocytic lymphohistiocytosis. Hematology Am Soc Hematol Educ Program 2005;1:82-8.

4. Fisman DN. Hemophagocytic syndromes and infection. Emerg Infect Dis 2000;6:601-8.

5. Ramachandran B, Balasubramanian S, Abhishek N, Ravikumar KG, Ramanan AV. Profile of hemophagocytic lymphohistiocytosis in children in a tertiary care hospital in India. Indian Pediatr 2011;48:31-5.

6. Tan LH, Lum LC, Omar SF, Kan FK. Hemophagocytosis in dengue: Comprehensive report of six cases. J Clin Virol 2012;55:79-82.

7. Fink J, Gu F, Vasudevan SG. Role of T cells, cytokines and antibody in dengue fever and dengue haemorrhagic fever. Rev Med Virol 2006; $16: 263-75$.

8. Martina BE, Koraka P, Osterhaus AD. Dengue virus pathogenesis: An integrated view. Clin Microbiol Rev 2009;22:564-81.

9. Ohga S, Matsuzaki A, Nishizaki M, Nagashima T, Kai T, Suda M, et al. Inflammatory cytokines in virus-associated hemophagocytic syndrome. Interferon-gamma as a sensitive indicator of disease activity. Am J Pediatr Hematol Oncol 1993;15:291-8.

10. Jordan MB, Allen CE, Weitzman S, Filipovich AH, McClain KL. How I treat hemophagocytic lymphohistiocytosis. Blood 2011;118:4041-52. 